\title{
12 \\ THE DICTIONARY OF CANADIAN BIOGRAPHY AND THE IRISH DIASPORA
}

\author{
DAVID A. WILSON
}

How do dictionaries of national biography fit into the context of transnational historical studies? This question is particularly apposite at a time when the very idea of transnationalism is being challenged by the resurgence of atavistic and frequently intolerant forms of nationalism, exemplified in varying degrees by the British withdrawal from the European Union, the election of Donald Trump as President of the United States of America, the politics of leaders such as Vladimir Putin, Tayyip Erdogan, and Viktor Orbán, and the rise of extreme right-wing parties in western Europe. As the post-World War II liberal order threatens to unravel, it is perhaps worthwhile remembering that there is nationalism, and then there is nationalism. 'When nationalism stunts the growth, and embitters the generous spirit which alone can produce generous and enduring fruits of literature', wrote the Irish Canadian politician and poet Thomas D'Arcy McGee in 1867, 'then it becomes a curse rather than a gain to the people among whom it may find favour, and to every other people who may have relations with such a bigoted, one-sided nationality.' ${ }^{\prime}$ The kind of nationalism that McGee endorsed had been expressed by his mentor, Charles Gavan Duffy, more than two decades earlier:

1 Montreal Gazette, 5 November 1867. See also T. D. McGee, 'The Mental Outfit of the New Dominion', in 1825-D'Arcy McGee-1925; A Collection of Speeches and Addresses, Together with a Complete Report of the Centennial Celebration of the Birth of the Honourable Thomas D'Arcy McGee at Ottawa, April 13th, 1925, ed. Charles Murphy (Toronto: MacMillan, 1937), 1-21. 
Nationality is broad, comprehensive, and universal; inspiring generous emotions, and encompassing noble ends. I, for one, will never consent to dwarf it down to the selfish schemes of a class in society, or the pedantic theories of a sect in politics. ${ }^{2}$

It was in this latter spirit that one of the generous and enduring fruits of Canadian literature was produced: the Dictionary of Canadian Biography/ Dictionnaire biographique du Canada $(D B C / D C B)$. Founded in 1959, and inspired by the example of Britain's Dictionary of National Biography, it was conceived as a 'biographical reference work for Canada of truly national importance, ${ }^{3}$ and intended to strengthen a sense of Canadian identity and unity. Although its promoters and funders sometimes spoke of its role in celebrating Canadian history, the Dictionary itself did not develop along such lines. With around 5,000 scholarly contributors writing in French and English, it has provided a multiplicity of viewpoints that are united by a desire to understand rather than praise Canada's past. It is, in short, a dictionary of national biography, not a dictionary of national hagiography.

Yet, in common with its counterparts in Britain, Ireland, the United States, Australia, New Zealand, and elsewhere, it also has a transnational dimension - and was intended to have one right from the start. James Nicholson, the English-born and Canadian-raised birdseed manufacturer whose bequest founded the $D B C / D C B$, stipulated in his will that 'the term "National" shall not be held to exclude ... those born in Canada who may have gained distinction in foreign lands, nor shall it exclude persons of foreign birth who have achieved eminence in Canada'. ${ }^{4}$ And so, a project that was established with national objectives in mind immediately took on characteristics of an international source base. It could not have been otherwise, given the large number of people who came to Canada from away, and given the large number of Canadians who made their mark outside the country, from missionaries in China to entertainers in the United States.

2 Quoted in Thomas D'Arcy McGee, Memoir of Charles Gavan Duffy, Esq., as a Student, Journalist, and Organizer (Dublin: W. Hogan, 1849), 26-27.

3 Quoted in 'About Us', Dictionary of Canadian Biography/Dictionnaire biographique du Canada, www.biographi.ca/en/about_us.php.

4 Will of James Nicholson, in Dictionary of Canadian Biography, Robarts Library, University of Toronto. 
In considering the national and international aspects of the $D B C / D C B$, at least five factors must be kept in mind. First, the biographies are based upon primary sources, and are subjected to a rigorous fact-checking and stylistic editorial process. Second, the $D B C / D C B$ makes every effort to include individuals who span the social spectrum-from prominent politicians such as John A. Macdonald to forgotten figures such as 'Alice G', who spent almost her entire life toiling in the laundry of Toronto's Asylum for the Insane. Third, the decision was made at the beginning to organise the biographies chronologically by death date, in a series of volumes beginning with the period from 1000 to 1700 , and moving gradually towards the present. Fourth, the $D B C / D C B$ is a fully bilingual project, in which all biographies are published in French and English; the general editor in Toronto works on an equal basis with the directeur general adjoint at Université Laval in Quebec. And fifth, a conscious effort is made to ensure that all regions of the country are fairly represented in the biographies.

As a result of its adherence to these principles, the $D B C / D C B$ has secured a national and international reputation for its high standards. In Canada, it received in 2012 the Governor General's Award for Popular History; outside the country, it has been praised by historians such as David Hackett Fischer as 'superior in coverage, documentation, and quality of writing' to the first British Dictionary of National Biography and the original Dictionary of American Biography. ${ }^{5}$ Fischer also drew attention to its accessibility. The $D B C / D C B$ is freely available online, with the result that it now has around 1.5 million visits each year.

At the same time, the approach of the $D B C / D C B$ poses several challenges that cannot easily be overcome. There is a tension, for example, between the insistence upon primary sources and the goal of including people from all walks of life. In practice, the biographies are heavily weighted towards those who were ensconced in the power structures of Canadian life, and for whom sufficient sources have survived; the lives of politicians, lawyers, and businessmen are far more numerous than those of farmers, fishers, and labourers. This has produced a severe gender imbalance. In the early volumes, up to 1900, women constituted between 3 and 6 per cent of the entries; the figure is currently running at 15 per cent for the 1930s, and will increase as the Dictionary moves closer to the present. ${ }^{6}$

5 David Hackett Fischer, Champlain's Dream (Toronto: Vintage Canada, 2009), 557.

6 See 'Women in the Dictionary of Canadian Biography/Dictionnaire biographique du Canada', Dictionary of Canadian Biography, www.biographi.ca/en/theme_women.html. 
Another problem is that the emphasis on quality has come at the price of quantity. With thorough fact checking, stylistic editing, and translation procedures in the Quebec and Toronto offices, there can be a long delay between the original submission of a biography and its appearance online. Apart from publishing some 30 'out of synchronisation' biographies that include figures such as Prime Minister Pierre Elliott Trudeau and the ice hockey star Maurice 'Rocket' Richard, the $D B C / D C B$ has not yet moved beyond those who died during the 1930s. The challenge has been compounded by severe government cutbacks that the $D B C / D C B$ experienced between 1989 and 1994; although stable funding has been restored, it has not matched earlier levels. There is a striking contrast between the output of the $D B C / D C B$ and that of the Oxford Dictionary of National Biography $(O D N B)$. While the former has published just over 8,600 biographies, consisting largely of people who died before 1940 , the latter has produced almost 60,000 biographies, including those of people who died as recently as 2013, such as the Northern Irish poet Seamus Heaney and the British politician Margaret Thatcher.

Inescapably, biographies that have been published over five decades reflect the dominant historiographical assumptions and levels of knowledge that existed at the time of writing. An unanticipated by-product is that the $D B C / D C B$ is a valuable source for Canadian historiography, as well as Canadian history. This also presents some problems. Language that was deemed acceptable in an earlier period is offensive to many people today. Some of the biographies that were written during the 1960s and 1970s used words such as 'savages', 'squaws', 'Eskimos', and 'negroes' to describe native peoples, indigenous women, the Inuit, and black Canadians. Conflicts between Europeans and natives were sometimes couched in terms of courageous Christian missionaries versus superstitious and violent pagan Indians. It was decided to replace currently offensive words with neutral language; to avoid an Orwellian rewriting of history, links to the original biographies were included. But the deeper problem of ethnocentric assumptions is much more difficult to handle; the task of recommissioning, rewriting, and re-editing earlier biographies is simply impossible without a massive and sustained infusion of cash. As we shall see, some of the issues arising from historiographical shifts and the availability (or existence) of primary sources also affect the $D B C / D C B$ 's coverage of Irish immigrants and their descendants in Canada. 


\section{The Irish}

In considering the relationship between the $D B C / D C B$ and global history, it is important to remember Kevin Kenny's distinction between cross-national and transnational history. Cross-national history involves a comparative analysis of immigrant experiences in different nation states, or regions and towns within those states; it examines such questions as settlement patterns, social mobility, labour history, and attachments to Old Country nationalism. Transnational history, in contrast, focuses on the flow of people between and among different nation states, and the demographic, economic, political, and cultural movements and interactions that occur in the process. As Kenny argues, both approaches are needed to provide a comprehensive framework for the study of migration history.

Dictionaries of national biography do not lend themselves to the kind of comparative analysis that Kenny recommends, but, precisely because of their focus on individuals, they can contribute to our understanding of transnational history. In Canada, the Irish are an ideal test case. They were the largest single ethnic group in English-speaking Canada for much of the nineteenth century, they had a significant impact on the country's political and religious history, and they were part of a broader transnational migration. ${ }^{8}$ Because most of them arrived during the first half of the nineteenth century, the fact that the $D B C / D C B$ does not currently venture much past 1940 is not a serious problem-although it does mean that some Irish immigrants and people of Irish ethnicity are still awaiting their turn.

Irish Canadian experiences were quite distinct from those of Irish Americans, and this difference can be discerned in the sequence and frequency of Irish entries in the $D B C / D C B$; the number of Irish-born Canadians in the dictionary picks up in the early nineteenth century, but starts to fall in the 1920s, as the mid-nineteenth-century migrants were dying out. In contrast to the United States, Irish migration to Canada was largely a pre-Famine phenomenon, and fell off sharply

7 Kevin Kenny, 'Diaspora and Comparison: The Global Irish as a Case Study', Journal of American History 90, no. 1 (2003): 134-62. doi.org/10.2307/3659794.

8 Donald Harman Akenson, The Irish in Ontario: A Study in Rural History (Kingston and Montreal: McGill-Queen's University Press, 1984); Cecil Houston and William J. Smyth, Irish Emigration and Canadian Settlement: Patterns, Links, \& Letters (Toronto: University of Toronto Press, 1990). 
during the mid-1850s. While Irish migrants in the United States were overrepresented in industrial parts of the country, those who came to Canada generally moved into the countryside rather than the towns and cities. A redaction of the 1871 census reveals that 60 per cent of the Irish Canadian ethnic group were Protestants, and that the Irish as a whole matched Canadian norms in terms of occupation, occupational success, and spatial distribution—although Irish Protestants had a significant edge over Irish Catholics. ${ }^{?}$

The major Irish institution in Canada was the Orange Order, which combined hyper loyalism with hyper anti-Catholicism, and which served as a mutual benefit society, a recreational outlet, and a welloiled patronage machine. By the early twentieth century, one in three adult Protestant males in Canada was a member of the Order. Moving beyond its Irish origins, it included Scots, Welsh, English, and American Protestants; there were also Mohawk lodges. The most Orange place in the early twentieth-century world was not the north of Ireland, but Newfoundland; its members were not Irish Protestants, but descendants of west country English fishermen. ${ }^{10}$

On the other side of the religious line, there were Irish Catholic St Patrick's Day parades, and numerous Catholic religious and political societies, most of which operated within a constitutional nationalist frame of reference. In the mid-nineteenth century, though, there was also a revolutionary Irish nationalist underground, with a significant Fenian presence. And anyone who was going to be a Fenian in loyalist, Orange Ontario was likely to be a very serious Fenian indeed. ${ }^{11}$

The Irish, Protestants and Catholics alike, energised every level of Canadian society. The Ontario school system was strongly influenced by Irish models; the North West Mounted Police drew on the example of the Royal Irish Constabulary; the low church character of Canadian Anglicanism stemmed from its Irish Protestant roots; the English-speaking Catholic Church spoke with a pronounced Irish accent; the Knights of

9 Gordon A. Darroch and Michael D. Ornstein, 'Ethnicity and Occupational Structure in Canada in 1871: The Vertical Mosaic in Historical Perspective', Canadian Historical Review 61, no. 3 (1980): 305-33. doi.org/10.3138/CHR-061-03-02.

10 Cecil Houston and William J. Smyth, The Sash Canada Wore: A Historical Geography of the Orange Order in Canada (Toronto: University of Toronto Press, 1980).

11 See, for example, Peter M. Toner, “"The Green Ghost”: Canada's Fenians and the Raids', EireIreland 16, no. 4 (Winter 1981): 27-47. 
Labor had a strong Irish component; and Irish Protestants and Catholics made their mark in such fields as administration, journalism, business, and the law. The lawyer who defended Patrick James Whelan-an Irish Canadian Fenian who was accused of assassinating Thomas D'Arcy McGee in 1868-was John Hillyard Cameron, a grand master of the Orange Order. The Crown counsel who successfully prosecuted Whelan was James O’Reilly, a Catholic lawyer who was born in County Mayo.

The $D B C / D C B$ captures much-but not all —of this reality. Of its more than 8,600 entries, around 800 have an Irish connection-ranging from St Brendan (who almost certainly never set foot in Canada) to William James Pentland, who migrated from County Down in 1911, founded the Dominion Grocery chain, and helped finance a stadium for Toronto's Ulster United football team. ${ }^{12}$ It is in no sense 'representative' of the Irish in Canada, nor does it claim to be. Owing to a combination of earlier historiographical assumptions and its reliance on primary sources, the $D B C / D C B$ contains more Irish Protestant colonial administrators than unskilled Irish Catholic labourers, and many more Irish men than Irish women. The Dictionary is particularly useful for its coverage of Irish Canadian politicians, soldiers, journalists, lawyers, businessmen, priests, and ministers - those who acquired prominence in their chosen fields. It is a rich resource for the principal personages in the Orange Order in Canada - a national variant of a transnational Orange network that operated within and beyond the British Empire. ${ }^{13}$

A good example is Ogle Gowan, the founder of the Grand Orange Lodge of British North America. Hereward Senior's biography in the $D B C / D C B$ discusses the Irish origins of Gowan's Orangeism, and shows how his conflict with another Irish Orangeman who came to Canada, George Perkins Bull, was carried across the Atlantic. Gowan also appears in the Dictionary of Irish Biography $(D I B)$. While the $D B C / D C B$ 's entry comes in at 4,000 words and is heavily weighted to his Canadian career, Bridget Hourican's biography in the DIB is a quarter of the length and

12 T. J. Oleson, 'Brendan (Bréanainn), Saint', Dictionary of Canadian Biography, vol. 1, published 1966; revised 1979, University of Toronto/Université Laval, 2003- , accessed 1 October 2018, www. biographi.ca/en/bio/brendan_saint_1E.html; David Roberts, 'Pentland, William James', Dictionary of Canadian Biography, vol. 16, published 2016, University of Toronto/Université Laval, 2003- , accessed 1 October 2018, www.biographi.ca/en/bio/pentland_william_james_16E.html.

13 Donald M. MacRaild, "Wherever Orange is Worn: Orangeism and Irish Migration in the 19th and early 20th Centuries', Canadian Journal of Irish Studies 28/29, no. 1 (Fall 2002-Spring 2003): 98-117. doi.org/10.2307/25515430. 
is equally divided between his Irish and Canadian activities. Hourican was able to draw not only on Senior's biography, but also on the work of Donald Harman Akenson and Bruce Elliott, with the result that Gowan's conflict with George Perkins Bull is brought into much sharper focus. The biographies complement each other; what the $D I B$ article lacks in length and Gowan's Canadian career, it gains in its fuller treatment of his Irish background and its engagement with more recent historiography. ${ }^{14}$

Cumulatively, the $D B C / D C B$ 's biographies on Orangeism reveal not only a great deal about the individuals who joined the organisation, but also about its changing character. We can trace the personal and political divisions within the movement, and the strong reaction against Orangeism from traditional Canadian Tories, colonial administrators, liberal Protestants, and Catholics throughout the country. By examining the genealogical information in the biographies, we can see how the Orange Order came to transcend its Irish origins. George Benjamin, who took over from Gowan as grand master in 1846 (and subsequently fought and lost a battle with him over the political direction of the order), was born in England. Moving into the second half of the nineteenth century, we encounter the biography of Oronhyatekha, a Mohawk physician who joined the Orange Order during the 1870s. Among the later biographies, we find black Canadians joining the order, such as George Washington Smith, a Toronto barber and spellbinding orator with a reputation as the leader of the city's 'colored colony', and Alfred Shadd, a physician and farmer in Melfort Saskatchewan, who proudly called himself a 'black Orangeman'. ${ }^{15}$

Although the Order was open to any adult Protestant male, it was driven by an anti-Catholicism that was rooted in its Irish background, and articulated forcefully by Irish-born leaders such as D'Alton McCarthy.

14 Hereward Senior, 'Gowan, Ogle Robert', Dictionary of Canadian Biography, vol. 10, University of Toronto/Université Laval, 2003- , accessed 1 October 2018, www.biographi.ca/en/bio/gowan_ ogle_robert_10E.html; Bridget Hourican, 'Gowan, Ogle Robert', Dictionary of Irish Biography, dib. cambridge.org.

15 Hereward Senior, 'Benjamin, George', Dictionary of Canadian Biography, vol. 9, University of Toronto/Université Laval, 2003- , accessed 1 October 2018, www.biographi.ca/en/bio/benjamin george_9E.html; Gayle M. Comeau-Vasilopoulos, 'Oronhyatekha', Dictionary of Canadian Biography, vol. 13, University of Toronto/Université Laval, 2003- , accessed 1 October 2018, www.biographi. ca/en/bio/oronhyatekha_13E.html; Barrington Walker, 'Smith, George Washington', Dictionary of Canadian Biography, vol. 15, University of Toronto/Université Laval, 2003-, accessed 1 October 2018, www.biographi.ca/en/bio/smith_george_washington_15E.html; Colin Argyle Thomson, 'Shadd, Alfred Schmitz', Dictionary of Canadian Biography, vol. 14, University of Toronto/Université Laval, 2003- , accessed 1 October 2018, www.biographi.ca/en/bio/shadd_alfred_schmitz_14E.html. 
Applying to Canada the Orange principles that he had learned from his father in Ireland, he spoke of the need to destroy what he called 'French ascendancy', if not by the ballot box then by bayonets. He became a prominent figure in the Equal Rights Association that was founded in 1889 with the objectives of abolishing separate schools for Catholics and preventing the French language from spreading to the Canadian northwest. These goals struck a responsive chord with the Orange rank and file, and persisted well into the twentieth century, when they took the form of a 'one language, one flag and one religion' reaction to bilingual and multicultural policies. ${ }^{16}$ Canadian Orangemen also played an active role in supporting Ulster Unionist resistance against Home Rule in Ireland, but these individuals are not represented in the $D B C / D C B$.

Surprisingly, given the Dictionary's policy of including 'those born in Canada who may have gained distinction in foreign lands', the most famous Canadian of all in the anti-Home Rule movement was omitted from the $D B C / D C B$ : Andrew Bonar Law. Born in New Brunswick in 1858 , he lived there until he was 12 years old, and according to the entry in the Oxford Dictionary of National Biography he 'never completely lost the Canadian accent acquired in his youth'. ${ }^{17}$ As the only British prime minister to have been born outside the United Kingdom, he naturally occupies a prominent place in the $O D N B$, yet for reasons unknown he was not included in the $D B C / D C B$. In striking contrast is Florence Lawrence, who was born to Irish parents in Hamilton, Ontario, left Canada at the age of four, and found fame as 'the Biograph Girl', the 'first movie star' in the world of silent films. She is included in the $D B C / D C B{ }^{18}$

On the Irish nationalist side of the equation, a number of Irish Canadians who supported Irish Home Rule are included in the Dictionary. Three in particular stand out: Edward Blake, Charles Ramsay Devlin, and Katherine Hughes. None of them was born in Ireland, but all had Irish roots- thus illustrating the persistence of Irish nationalist thought and feeling among the second and third generations of Irish Canadians. Edward Blake, a Protestant who was born in Canada of Irish parents, served as the Liberal

16 See, for example, Jock V. Andrew, Bilingual Today, French Tomorrow: Trudeau's Master Plan and How It Can Be Stopped (Richmond Hill, Ont.: BMG Publications Ltd, 1977).

17 E. H. H. Green, 'Law, Andrew Bonar (1858-1923)', Oxford Dictionary of National Biography, Oxford University Press, 2004; online edn, January 2011, accessed 28 September 2018. doi.org/ 10.1093/ref:odnb/34426.

18 Or will be: Cecilia Morgan, 'Florence Lawrence', Dictionary of Canadian Biography, forthcoming, www.biographi.ca. 
premier of Ontario and the leader of the federal Liberal Party; among other things, he fought against a bill to incorporate the Orange Order in Canada. (The bill passed.) After losing two general elections to the Conservatives, he left Canadian politics in 1892, moved to Ireland, and became a Home Rule MP for South Longford. At a time when the Irish Parliamentary Party was financially strapped and deeply divided, he raised Irish Canadian funds for the cause, donated a large amount of money himself, and played an important role in uniting the party's Parnellite and anti-Parnellite factions. But his attempts to apply Canadian and Australian examples of self-government to the Irish situation fell flat. In the words of his $D B C / D C B$ biographers, 'His model of Irish nationalism, which was set within a federalist, imperial framework, lacked broad appeal in Ireland, and his limited grasp of British and Irish politics prevented much open leadership on his part, a role many had expected'. ${ }^{19}$ One is reminded of another figure in the $D B C / D C B$, Goldwin Smith, who commented in the course of his attacks on Home Rule that 'Statesmen might as well provide the Irish people with Canadian snowshoes ... as extend to them the Canadian Constitution'. ${ }^{20}$ The $D I B$ also has an entry on Blake; it is much shorter than the Canadian one, and spends equal time on his Canadian and Irish experiences. ${ }^{21}$ As is the case with Ogle Gowan, the two biographies of Blake operate within distinct national frameworks, but together they illuminate the transnational character of his career.

Charles Ramsay Devlin's career not only underlines the importance of second-generation Irish Canadian nationalism, but also reveals the connections that could arise between French Canadian and Irish politicians. The common denominator was Catholicism. Devlin came from an Irish Canadian Catholic family with strong Irish nationalist convictions; his uncle, Bernard Devlin (who wound up as a federal Liberal MP during the 1870s), had urged Irish American revolutionaries in 1848 to aid and abet an Irish revolution by invading Canada. With French Canadian support, Charles Devlin in 1891 became a Liberal MP in Quebec, only to break with the party six years later for not taking a strong enough stand on the question of educational rights for Catholics in the province of Manitoba.

19 Ben Forster and Jonathan Swainger, 'Blake, Edward', Dictionary of Canadian Biography, vol. 14, University of Toronto/Université Laval, 2003- , accessed 1 October 2018, www.biographi.ca/en/bio/ blake_edward_14E.html.

20 Ramsay Cook, 'Smith, Goldwin', Dictionary of Canadian Biography, vol. 13, University of Toronto/ Université Laval, 2003- , accessed 1 October 2018, www.biographi.ca/en/bio/smith_goldwin_13E. html.

21 David Murphy, 'Blake, Edward', Dictionary of Irish Biography, dib.cambridge.org. 
Appointed Canada's first trade commissioner to Ireland, he became an Irish nationalist MP for Galway and the secretary of the United Irish League. On his return trips to Canada, he joined French Canadian politicians such as Henri Bourassa in attacking British imperialism and advocating Home Rule for Ireland. Devlin does not appear in the $D I B$, but his $D B C / D C B$ entry is a valuable resource for anyone interested in the international dimensions of Irish nationalism. ${ }^{22}$

This is also true of Katherine Hughes, the only female Irish nationalist to appear in the $D B C / D C B$. Born in Prince Edward Island in 1876, she was a remarkable woman in many respects: a teacher, missionary to indigenous peoples, biographer, journalist, cofounder of the Canadian Women's Press Club, the first provincial archivist of Alberta, and assistant in the London office of the province's agent general. In London during the height of the Home Rule crisis, she converted from Canadian imperialism to Irish nationalism. After the Easter Rising of 1916, she brought the case for Irish independence to Canadian audiences, and during the Anglo-Irish war of 1919-21 she became a key organiser in the Self-Determination League for Ireland, travelling throughout Canada, the United States, Australia, New Zealand, and France in the service of Sinn Fein-a global figure if ever there was one. ${ }^{23}$

Although Irish Canadian nationalists such as Hughes, Devlin, and Blake generated intense controversy in Canada, and were pilloried by loyalists as traitors to the British Empire, they were not a direct threat to the Canadian state. It was a different story with the Fenians, who between 1866 and 1871 made four attempts to invade Canada. The treatment of the Fenians in the $D B C / D C B$ demonstrates the way in which these transnational revolutionaries were viewed through a Canadian national (and sometimes implicitly nationalist) lens. When their biographies were written, the dominant view in Canadian historiography was that the Fenians were, in Donald Creighton's words, 'a crew of grandiloquent clowns and

22 Alexander Reford, 'Devlin, Charles Ramsay', Dictionary of Canadian Biography, vol. 14, University of Toronto/Université Laval, 2003- , accessed 1 October 2018, www.biographi.ca/en/ bio/devlin_charles_ramsay_14E.html. See also J.-C. Bonenfant, 'Devlin, Bernard', Dictionary of Canadian Biography, vol. 10, University of Toronto/Université Laval, 2003- , accessed 1 October 2018, www.biographi.ca/en/bio/devlin_bernard_10E.html. For Bernard Devlin's support for an American Irish invasion of Canada in 1848, see New York Daily Tribune, 25 August 1848.

23 Pádraig Ó Siadhail, 'Hughes, Katherine (Catherine) Angelina', Dictionary of Canadian Biography, vol. 15, University of Toronto/Université Laval, 2003- , accessed 1 October 2018, www.biographi.ca/ en/bio/hughes_katherine_angelina_15E.html. See also his award-winning book, Katherine Hughes: A Life and A Journey ([Newcastle, Ontario]: Penumbra Press, 2014). 
vainglorious incompetents' ${ }^{24}$ It may not be entirely coincidental that, as Donald Wright points out in the $D B C / D C B$ entry on Creighton, he was descended from Presbyterians in County Derry. ${ }^{25}$

This view comes across clearly in C. P. Stacey's entry on John O'Neill, leader of the Fenian attempt to invade Canada in 1866. 'It is hard to believe that O'Neill was a man of much intelligence,' wrote Stacey:

for the idea of righting Irish wrongs by attacking Canada, of which he was the most active exponent, was essentially stupid. He was egotistical and credulous. He seems however to have been a brave soldier and a sincere Irish patriot. Unlike many Fenian leaders, he was ready to risk life and liberty for the cause he believed in. ${ }^{26}$

The Fenians were dismissed and mocked as Celtic cranks with a typically 'Irish' hare-brained scheme to liberate Ireland by invading Canada. Such an approach not only reveals a failure of historical imagination, but also reduces complex realities to the level of caricature; ultimately, it tells us more about Canadian historiography than about Fenian motivations and strategies. In contrast, Desmond McCabe's entry on O'Neill in the DIB points out that, rather than being 'essentially stupid', the idea of O'Neill and his fellow Fenians was to 'exploit Anglo-American tensions and perhaps spark a war between Britain and America'. ${ }^{27}$

At least O'Neill made it into the $D B C / D C B$. This was not the case with at least three Irish Canadians from Toronto who became prominent figures in international Fenianism: Edward O'Meagher Condon, William Mackey Lomasney, and Thomas Francis Bourke. Condon's speech from the dock in 1867, with its closing cry of 'God Save Ireland', became a source of inspiration for subsequent generations of Irish nationalists. His friend Lomasney conducted a guerrilla campaign in Cork after the failed Fenian rising of 1867 , and in 1884 blew himself up while planting a bomb under London Bridge. Bourke led the Tipperary contingent of the 1867 rising; the speech he gave during his trial was widely regarded as one of the finest

24 Donald Creighton, The Road to Confederation: The Emergence of Canada, 1863-1867 (Toronto: MacMillan, 1964), 304.

25 Donald Wright, 'Creighton, Donald Grant', Dictionary of Canadian Biography, vol. 20, University of Toronto/Université Laval, 2003- , accessed 1 October 2018, www.biographi.ca/en/ bio/creighton_donald_grant_20E.html. See also his Donald Creighton: A Life in History (Toronto: University of Toronto Press, 2015).

26 C. P. Stacey, 'O'Neill, John', Dictionary of Canadian Biography, vol. 10, University of Toronto/ Université Laval, 2003-, accessed 1 October 2018, www.biographi.ca/en/bio/o_neill_john_10E.html. 27 Desmond McCabe, 'O'Neill, John', Dictionary of Irish Biography, dib.cambridge.org. 
in the nationalist tradition. Although they are absent from the $D B C / D C B$, they all feature in the $D I B$. But the ways in which they were radicalised in Orange Toronto are absent in the $D I B$, and Lomasney's origins are misplaced in Cincinnati. Here we have good examples of the ways in which transatlantic figures in national biographies can fall between the cracks. Operating within a Canadian frame of reference, the $D B C / D C B$ missed their Irish importance; operating with an Irish frame of reference, the $D I B$ missed the significance of their Canadian background. ${ }^{28}$

For the most part, the Irish in the $D B C / D C B$ were more engaged in the issues of Canada than events in the Old Country. Their Canadian careers, though, were often deeply rooted in their Irish origins. Early nineteenthcentury harbingers of responsible government, such as Robert Thorpe and William Weekes, came out of an Anglo-Irish Whig tradition that was equally suspicious of popular radicalism and arbitrary power. As their biographer, Graeme Patterson, noted, they tended 'to understand local politics in terms of Irish analogies. ${ }^{29}$ Personal ambition was an equally powerful, or possibly an even more powerful, motivator as well. Part of the same circle was William Warren Baldwin, whose family had left Ireland to escape the 'horrors of domestic war' in 1798. His biographer, Robert Fraser, observed that Baldwin drew on 'Irish models for the question of the sovereignty of colonial legislatures', and that he played a leading role in

the transition from the idea of ministerial responsibility (that is, the legal responsibility of the king's ministers to the legislature enforced by impeachment) to the idea of responsible government (which meant the political responsibility of individual ministers or the cabinet to the elected house). ${ }^{30}$

28 Owen McGee, 'Condon, Edward O'Meagher'; Desmond McCabe and Owen McGee, 'Lomasney, William Francis Mackey'; James Quinn, 'Bourke, Thomas Francis', Dictionary of Irish Biography, dib.cambridge.org.

29 G. H. Patterson, 'Thorpe, Robert', Dictionary of Canadian Biography, vol. 7, University of Toronto/Université Laval, 2003- , accessed 1 October 2018, www.biographi.ca/en/bio/thorpe robert_7E.html; G. H. Patterson, 'Weekes, William', Dictionary of Canadian Biography, vol. 5, University of Toronto/Université Laval, 2003-, accessed 1 October 2018, www.biographi.ca/en/bio/ weekes_william_5E.html.

30 Robert L. Fraser, 'Baldwin, William Warren', Dictionary of Canadian Biography, vol. 7, University of Toronto/Université Laval, 2003-, accessed 1 October 2018, www.biographi.ca/en/bio/ baldwin_william_warren_7E.html. 
William Warren's son, Robert Baldwin, carried on the tradition, retained a keen sense of Irishness, and would be a key figure in turning the idea of responsible government into reality during the $1840 \mathrm{~s}^{31}$

The $D B C / D C B$ entries also shed light on the Irish contributions to Canadian Confederation. Among pro-Confederate Irish politicians, such as Edward Kenny in Nova Scotia and Edward Whelan in Prince Edward Island, by far the most important was D'Arcy McGee. 'Much of McGee's Canadian programme', notes his biographer Robin Burns, 'was derived from the nationalist theories of Young Ireland'. ${ }^{32}$ But the Irish connection could cut both ways; some Irish Canadians attacked the proposed union of the Canadian provinces in the same language that they attacked the existing union of Great Britain and Ireland. They include the New Brunswick journalist and politician Timothy Warren Anglin, although his biography focuses on his practical objections to Confederation rather than his use or misuse of Irish analogies. ${ }^{33}$

Similar lines of inquiry could be pursued for Irishmen or their descendants who helped to shape colonial administration, religious life, the labour movement, and literary traditions in Canada. A major reason why the Irish Whig Lord Gosford was appointed governor-in-chief of British North America in 1835 was because the government 'hoped that he might be able to apply in Lower Canada the techniques of conciliation that he had employed so successfully in Ireland'. (The hope proved in vain; as his biographer Phillip Buckner tersely remarked, 'Lower Canada was not Ireland'.) ${ }^{34}$ Irish Catholic bishops such as John Joseph Lynch, who viewed the Irish as 'a chosen people destined to preserve and extend the true faith throughout the world', brought Irish sensibilities to the English-speaking

31 Michael S. Cross and Robert Lochiel Fraser, 'Baldwin, Robert', Dictionary of Canadian Biography, vol. 8, University of Toronto/Université Laval, 2003- , accessed 1 October 2018, www.biographi.ca/en/ bio/baldwin_robert_8E.html.

32 Robin B. Burns, 'McGee, Thomas D’Arcy', Dictionary of Canadian Biography, vol. 9, University of Toronto/Université Laval, 2003- , accessed 1 October 2018, www.biographi.ca/en/bio/mcgee_ thomas_d_arcy_9E.html.

33 William M. Baker, 'Anglin, Timothy Warren', Dictionary of Canadian Biography, vol. 12, University of Toronto/Université Laval, 2003- , accessed 1 October 2018, www.biographi.ca/en/bio/ anglin_timothy_warren_12E.html.

34 Phillip Buckner, 'Acheson, Archibald, 2nd Earl of Gosford', Dictionary of Canadian Biography, vol. 7, University of Toronto/Université Laval, 2003- , accessed 1 October 2018, www.biographi.ca/ en/bio/acheson_archibald_7E.html. 
Catholic Church in Canada. ${ }^{35}$ A host of Irish Anglican, Presbyterian, and Methodist ministers in the $D B C / D C B$ injected Protestant Irish traditions (frequently with large doses of anti-Catholicism) into the country. When it comes to the labour movement in Canada, the Dictionary has dozens of biographies on trade union leaders, some of whom combined labour activism with Orange politics. In the field of literature, the $D B C / D C B$ has biographies of a dozen Irish poets whose work has largely been forgotten today. Interestingly, all of them were Protestant. Conspicuous by his absence was the poet laureate of Canadian Fenianism, James McCarroll. He was quietly and effectively written out of Canadian history during the nineteenth century, and was not included in the Dictionary because the sources seemed too thin. ${ }^{36}$

There are books waiting to be written on these subjects, and the biographies and bibliographies of the $D B C / D C B$ are a rich resource for all of them. Anyone writing a general history of the Irish in Canada could also benefit enormously from the Dictionary, as could anyone working on the Irish diaspora-providing its limitations are kept in mind. Operating within a national framework, the $D B C / D C B$ is naturally stronger on Irish contributions to Canadian life than on the transnational dimensions of Irish Canadian experiences. But it does not ignore those transnational dimensions (Andrew Bonar Law excepted), and it can point readers in diasporic directions. Perhaps, in the end, that is enough.

Some Irishmen and women with transnational careers can be traced through different national biographies. D'Arcy McGee, for example, appears in four of them: the $D B C / D C B$, the $D I B$, the $O D N B$, and the American National Biography. Others, such as Charles Ramsay Devlin and Katherine Hughes, are confined to one. Now that these dictionaries are online, with easy search functions, it is well worth considering how they can be made to speak to one another. Keith Thomas has written that 'One day perhaps we may have a database so vast that its claim to be a true national biography will be incontrovertible. ${ }^{37}$ There is no reason, in principle, why

35 Charles W. Humphries, 'Lynch, John Joseph', Dictionary of Canadian Biography, vol. 11, University of Toronto/Université Laval, 2003- , accessed 1 October 2018, www.biographi.ca/en/bio/ lynch_john_joseph_11E.html.

36 More recently, Michael A. Peterman has done prodigious work in tracking down information on McCarroll, and rescuing him from obscurity. See his Delicious Mirth: The Life and Times of James McCarroll (Montreal and Kingston: McGill-Queen's University Press, 2018).

37 Keith Thomas, Changing Conceptions of National Biography: The Oxford DNB in Historical Perspective (Cambridge: Cambridge University Press, 2005), 56. doi.org/10.1017/CBO9780511497582. 
this could not be extended to a true international biography-a hightech revival of the seventeenth-century dreams of universal biography. In practice, however, the barriers to such a project are formidable. Not only do the various national biographies have different approaches, funding models, and degrees of accessibility; some of them operate under financial constraints that preclude such an initiative. A system of transnational cross-referencing is doubtless desirable. It would be useful, for example, for students of the Irish diaspora who read the biography of Katherine Hughes to get links to the prominent Irish cultural and political figures whom she met in London; two of them, Pádraic Ó Conaire and Arthur O'Brien, are in the $D I B .{ }^{38}$ But the task of adding transnational references to all biographies in a national dictionary is truly daunting.

It comes down to a question of resources and priorities. In the case of the $D B C / D C B$, the staff in both the Toronto and Quebec offices are working to complete the current volume. Any increase in funds would be directed towards tasks of completing the next volume (dealing with those who died during the 1940s), and correcting or recommissioning earlier biographies. A zero-sum situation exists: time spent on transnational projects is time taken away from pressing current objectives. Having said that, there is no reason why the $D B C / D C B$ and its counterparts elsewhere should not develop a greater consciousness of the international context in which their subjects lived, and within which the dictionaries themselves operate: in the case of the $D B C / D C B$, this can be done by placing more emphasis on the extra-Canadian activities of its subjects, highlighting transnational connections in the special thematic projects, and keeping lines of communication open with other dictionaries of national biography, to see what might be possible as events unfold. These are, without question, very modest goals. But at least they have the benefit of being realistic ones.

38 Lesa Ní Mhunghalle, 'Ó Conaire, Pádraic'; Kelko Inoue, 'O’Brien, Arthur Patrick Donovan', Dictionary of Irish Biography, dib.cambridge.org. 
This text is taken from 'True Biographies of Nations?': The Cultural Journeys of Dictionaries of National Biography, edited by Karen Fox, published 2019 by ANU Press, The Australian National University, Canberra, Australia.

doi.org/10.22459/TBN.2019.12 